\title{
German Cockroach Proteases and Protease-Activated Receptor-2 Regulate Chemokine Production and Dendritic Cell Recruitment
}

\author{
Scottie B. Day ${ }^{\mathrm{a}}$ John R. Ledford ${ }^{\mathrm{a}}$ Ping Zhou ${ }^{\mathrm{a}} \quad$ lan P. Lewkowich ${ }^{\mathrm{b}}$ \\ Kristen Page ${ }^{a, c}$

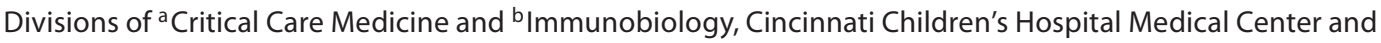 \\ Cincinnati Children's Research Foundation, and 'Department of Pediatrics, University of Cincinnati, \\ Cincinnati, Ohio, USA
}

\section{Key Words}

Allergy $\cdot$ Chemokines $\cdot$ Immune response $\cdot$ Dendritic cell $•$

Murine $\cdot$ Pulmonary

\begin{abstract}
We recently showed that serine proteases in German cockroach (GC) feces (frass) decreased experimental asthma through the activation of protease-activated receptor (PAR)2. Since dendritic cells (DCs) play an important role in the initiation of asthma, we queried the role of GC frass proteases in modulating CCL20 (chemokine C-C motif ligand 20) and granulocyte macrophage colony-stimulating factor (GM-CSF) production, factors that regulate pulmonary DCs. A single exposure to GC frass resulted in a rapid, but transient, increase in GM-CSF and a steady increase in CCL20 in the airways of mice. Instillation of protease-depleted GC frass or instillation of GC frass in PAR-2-deficient mice significantly decreased chemokine release. A specific PAR-2-activating peptide was also sufficient to induce CCL20 production. To directly assess the role of the GC frass protease in chemokine release, we enriched the protease from GC frass and confirmed that the protease was sufficient to induce both GM-CSF and CCL20 production in vivo. Primary airway epithelial cells produced both GM-CSF and CCL20 in a prote-
\end{abstract}

\section{KARGER}

Fax +4161306 1234

E-Mail karger@karger.ch

www.karger.com (c) 2011 S. Karger AG, Basel

Accessible online at: www.karger.com/jin ase- and PAR-2-dependent manner. Finally, we show a decreased percentage of myeloid DCs in the lung following allergen exposure in PAR-2-deficient mice compared to wildtype mice. However, there was no difference in GC frass uptake. Our data indicate that, through the activation of PAR2 , allergen-derived proteases are sufficient to induce CCL20 and GM-CSF production in the airways. This leads to increased recruitment and/or differentiation of myeloid DC populations in the lungs and likely plays an important role in the initiation of allergic airway responses.

Copyright ๑ 2011 S. Karger AG, Basel

\section{Introduction}

Airborne allergens are known to induce asthma in predisposed individuals. Many of these allergens contain protease activity which modulates the inflammatory response. Endogenous proteases in a variety of allergens, including house dust mite [1], mold [2] and cockroach [3], have been shown to cleave and activate protease-activated receptor (PAR)-2 in cell culture models. PARs are a family of G-coupled receptors through which a number of extracellular proteases can signal directly to cells via the cleavage and activation of the receptors on the cell surface 
[4]. PAR-2 is expressed by many cells in the lung, including airway epithelial cells [1], alveolar macrophages [5], neutrophils [6] and mast cells [7]. We recently showed that serine proteases in German cockroach (GC) feces (frass) proteases played a role in modulating airway hyperresponsiveness and mucin production [8] through the activation of PAR-2 [9]. Our data showed that mucosal sensitization to an allergen required the active proteases to mediate a full inflammatory response. What is still unclear, however, is the mechanism by which allergenderived proteases initiate allergic airway inflammation.

Dendritic cells (DCs) are potent antigen-presenting cells which play a role in both the innate and adaptive immune response. In the lung, DCs are normally found at the epithelial cell layer, where they sample inhaled allergens present in the airways [10]. However, DC turnover is high, and immature DCs are continuously recruited from the circulation along chemokine gradients. Moreover, after allergen inhalation in both humans [11] and mice [12], DC recruitment is further enhanced through the release of CCL20 from the epithelium. CCL20 is a unique ligand for the chemokine CCR6 which is selectively expressed on circulating immature DCs [13]. Recently, house dust mite (HDM) allergen has been shown to increase CCL20 mRNA and protein secretion from human airway epithelium through a $\beta$-glucan-dependent pathway [14].

In addition to the production of CCL20, epithelial cells can also enhance immune responses through the release of granulocyte macrophage-colony stimulating factor (GM-CSF), a factor which induces the development of pro-asthmatic myeloid DCs (mDCs) while actively suppressing the development of plasmacytoid DCs [15], a DC subset that has been shown be tolerogenic in murine asthma models [16]. Overexpression of GM-CSF has been shown to overcome the necessity for adjuvant in the development of eosinophilia and Th2 differentiation in response to purified allergen (recombinant Der p1, ovalbumin) $[17,18]$. Neutralization of GM-CSF using a specific antibody was shown to reduce HDM-induced eosinophilia, Th2 cytokine production and airway hyperresponsiveness [17]. However, little is known regarding the induction of CCL20 or GM-CSF by specific allergenic components.

Since allergen-associated proteases and PAR-2 clearly play a role in allergic airway inflammation $[8,9]$, and due to the importance of GM-CSF and CCL20 in the recruitment and differentiation of mDCs in the lung, we hypothesized that allergen-associated proteases may be responsible for induction of CCL20 and GM-CSF production in vivo. In this report, we demonstrate that serine proteases in GC frass, through the activation of PAR-2, can regulate CCL20 and GM-CSF production, leading to increased pulmonary $\mathrm{mDC}$ levels in the lung. These data highlight the possibility that proteases in allergens are important factor(s) that make GC frass allergenic.

\section{Materials and Methods}

\section{Cockroach Frass}

The fecal remnants (frass) from one cage of GCs were transferred to a sterile container and stored at $4^{\circ} \mathrm{C}$. GC frass was resuspended in PBS (divalent-cation free; Gibco/Invitrogen, Carlsbad, Calif., USA) made with endotoxin-free double-distilled water (Sigma-Aldrich Corp., St. Louis, Mo., USA) for $2 \mathrm{~h}$ at $4^{\circ} \mathrm{C}$ while rocking. Extracts were centrifuged to remove debris $(10,000 \mathrm{~g}$ for $5 \mathrm{~min}$ at $4^{\circ} \mathrm{C}$ ), supernatants harvested and total protein was measured using the Bio-Rad Protein Assay Dye (Bio-Rad, Hercules, Calif., USA). To inhibit protease activity, frass was pretreated with aprotinin (Sigma-Aldrich; $10 \mu \mathrm{g} / \mathrm{ml}$ for $30 \mathrm{~min}$ at $37^{\circ} \mathrm{C}$ ) prior to use. The same concentration of aprotinin was added to PBS and used as a control. Protease activity was determined using the Azocoll assay as previously described $[19,20]$. GC frass was determined to contain $12.3 \mathrm{U} / \mathrm{mg}$ and aprotinin treatment inhibited $85 \%$ of the protease activity [21], and will hence be referred to as protease-depleted GC frass. Endotoxin levels were measured using the Limulus Amebocyte Lysate Assay (Lonza, Walkersville, Md., USA). Some GC frass was labeled with AlexaFluor-405 (Invitrogen) according to the manufacturer's specifications.

\section{Protease Enhancement of GC Frass}

GC frass was run through a size exclusion column (Sephadex G75 superfine, Amersham Pharmacia, Piscataway, N.J., USA) at $0.5 \mathrm{ml} / \mathrm{min}$ using a $50-\mathrm{mm}$ sodium phosphate buffer, $\mathrm{pH}$ 7.4. Fractions $(1 \mathrm{ml})$ were assessed for protease activity using the Azocoll assay as previously described $[19,20]$. Protease activity was detected in a single peak eluted between roughly 20 and $45 \mathrm{kDa}$. The fractions in the protease peak were combined, dialyzed against double-distilled $\mathrm{H}_{2} \mathrm{O}$, and concentrated using a Centrivap (Labconco, Kansas City, Mo., USA). A prepacked HiTrap Benzamidine FF affinity column (GE Healthcare, Piscataway, N.J., USA) was equilibrated with 5 column volumes of binding buffer $(20 \mathrm{mM}$ $\mathrm{NaPO}_{4}, \mathrm{pH} 7.5$, with $0.5 \mathrm{M} \mathrm{NaCl}$ ) prior to the addition of the protease sample. The concentrated protease peak was loaded onto the HiTrap column, the column was washed with 10 column volumes of binding buffer and then the protease was eluted with 10 column volumes of binding buffer containing $20 \mathrm{mM} p$-aminobenzamidine (Spectrum Chemical Corp, Gardenia, Calif., USA). One-milliliter fractions were collected and protease activity in each fraction was assayed by the Azocoll assay $[19,20]$. The fractions containing protease activity were combined, dialyzed against double-distilled $\mathrm{H}_{2} \mathrm{O}$ and measured for protein concentration and protease activity as described above. Table 1 shows the amount of protein, enzymatic activity and endotoxin in the starting material GC frass and in the final column-purified protease sample. The protease-enhanced GC frass was frozen in aliquots and used for the remainder of the studies. 
Table 1. Characteristics of GC frass and the protease-enriched GC frass

\begin{tabular}{lllll}
\hline & $\begin{array}{l}\text { Protein } \\
\mathrm{mg} / \mathrm{ml}\end{array}$ & $\begin{array}{l}\text { Activity } \\
\text { units }\end{array}$ & $\begin{array}{l}\text { Activity/ } \\
\text { mg protein }\end{array}$ & $\begin{array}{l}\text { Endotoxin } \\
\text { EU/mg protein }\end{array}$ \\
\hline GC frass & 4.1 & 50.3 & 12.3 & 28,585 \\
Protease & 0.35 & 31.5 & 90 & 14.14 \\
\hline
\end{tabular}

The protease activity in GC frass was enriched by removal of other GC frass components via column chromatography. Both the original (GC frass) and the enriched component (protease) were analyzed for protein, protease activity and endotoxin levels.

Animals and Exposure Protocol

Six-week-old female BALB/c and PAR-2-deficient mice were obtained from Jackson Laboratory (Bar Harbor, Me., USA). The PAR-2 mice were backcrossed onto the BALB/c background for 10 generations. Mice were anesthetized with ketamine $(45 \mathrm{mg} / \mathrm{kg}) /$ xylazine $(8 \mathrm{mg} / \mathrm{kg})$ prior to PBS or GC frass $(40 \mu \mathrm{g} / 40 \mu \mathrm{l})$ exposure by a single instillation as previously described [22]. In some cases, the PAR-2-activating peptide (PAR-2AP: SLIGRL-NH $\mathrm{N}_{2}$ ) or PAR-control peptide (PAR-2CP; LSIGRL-NH ${ }_{2}$; both used at a concentration of $400 \mu \mathrm{g} / 40 \mu \mathrm{l}$ in PBS) obtained from Peptides International (Louisville, Ky., USA) or enriched protease $(0.5$ units $/ 40 \mu \mathrm{l}$ ) were administered by intratracheal instillation. Mice were given a lethal dose of sodium pentobarbital 1-20 h later. Animal care was provided in accordance with NIH guidelines. These studies were approved by the Cincinnati Children's Hospital Medical Center Institutional Animal Care and Use Committee.

\section{Assessment of Airway CCL20 and GM-CSF Levels}

Lungs were lavaged with $1 \mathrm{ml}$ of Hanks' balanced salt solution without calcium or magnesium. The lavage fluid was centrifuged (300 $\mathrm{g}$ for $10 \mathrm{~min}$ ); the supernatant was removed and immediately stored at $-80^{\circ} \mathrm{C}$. The bronchoalveolar lavage (BAL) fluid was analyzed for CCL20 and GM-CSF using an ELISA kit purchased from R\&D Systems (Minneapolis, Minn., USA). In some cases, whole lungs were removed and snap frozen in liquid nitrogen for PCR analysis.

\section{Mouse Tracheal Epithelial Cells}

Tracheas from 4-week-old wild-type or PAR-2-deficient mice were removed from the thyroid cartilage to the level of bifurcation and incubated in Pronase $(1 \mathrm{mg} / \mathrm{ml}$; Roche Applied Science, Indianapolis, Ind., USA) and incubated ( $18 \mathrm{~h} \times 4^{\circ} \mathrm{C}$ while rocking). The next day, 10\% FBS and $1 \mathrm{mg} / \mathrm{ml}$ DNase (Sigma-Aldrich) was added to the tube and inverted multiple times. The trachea was discarded; cells were washed and plated onto a cell culture plate with Primaria surface treatment (BD Biosciences, Bedford, Mass., USA) for $4 \mathrm{~h}$ to remove fibroblasts. Nonattached cells were washed, counted and plated in DMEM/F12 (50/50) containing L-glutamine $(2 \mathrm{mM})$, penicillin $(100 \mathrm{U} / \mathrm{ml}) /$ streptomycin $(100 \mu \mathrm{g} / \mathrm{ml})$ $\mathrm{NaHCO}_{3}(1 \mathrm{mM})$, FBS (5\%), cholera toxin $(0.1 \mu \mathrm{g} / \mathrm{ml})$, mouse EGF $(0.5 \mathrm{ng} / \mathrm{ml})$, amphotericin $\mathrm{B}(0.25 \mu \mathrm{g} / \mathrm{ml})$, bovine pituitary extract $(50 \mu \mathrm{g} / \mathrm{ml})$, insulin-transferrin-selenium $\mathrm{X}$, and retinoic acid $(0.1$ $\mathrm{ng} / \mathrm{ml})$. Mouse tracheal epithelial cells were grown on collagencoated 6-well tissue culture plates until confluent. Cells were treated with PBS, aprotinin in PBS, GC frass $(1 \mu \mathrm{g} / \mathrm{ml})$ or GC frass pretreated with aprotinin for $18 \mathrm{~h}$. Supernatants were harvested, clarified, and analyzed for CCL20 and GM-CSF by ELISA.

\section{Flow Cytometry}

Wild-type or PAR-2-deficient mice were given a single intratracheal instillation of PBS or AF405-labeled GC frass $(40 \mu \mathrm{g} / 40$ $\mu \mathrm{g})$. Twenty hours later, whole lungs were removed and placed in RPMI-1640 containing Liberase CI $(0.5 \mathrm{mg} / \mathrm{ml}$; Roche Diagnostics, Indianapolis, Ind., USA) and DNase I ( $0.5 \mathrm{mg} / \mathrm{ml}$; Sigma, St. Louis Mo., USA) at $37^{\circ} \mathrm{C}$ for $45 \mathrm{~min}$. The tissue was forced through a $70-\mu \mathrm{m}$ cell strainer, and red blood cells were lysed with ACK lysis buffer (Invitrogen). Cells were washed with RPMI containing $10 \% \mathrm{FBS}$, counted and $1 \times 10^{6}$ cells were used for staining. Staining reactions were performed at $4^{\circ} \mathrm{C}$ following incubation with Fc block (mAb 2.4G2) for 30 min. mDCs (CD11c+, CD11b+, Gr1-, CD317-) were quantified using anti-CD11c-APC (HL3), anti-CD11b-PE-Cy7 (M1/70), and anti GR-1-APC-Cy7 (RB6-8C5), anti-CD317-FITC (eBio129c). Dead cells were excluded using 7-AAD. All antibodies were purchased from eBioscience (San Diego, Calif., USA). Data were acquired with an LSRII flow cytometer (BD Biosciences, San Jose, Calif., USA). Spectral overlap was compensated using the FACSDiVa software (BD Biosciences) and analyzed using FlowJo software (Treestar Inc., Ashland, Oreg., USA).

\section{Statistical Analysis}

When applicable, statistical significance was assessed by oneway analysis of variance (ANOVA). Differences identified by ANOVA were pinpointed by Student-Newman-Keuls' multiple range test.

\section{Results}

\section{A Single Intratracheal Instillation of GC Frass Increased CCL20 and GM-CSF Expression in the BAL Fluid}

To measure GC frass-induced production of CCL20 and GM-CSF, naïve wild-type mice were given a single intratracheal instillation of PBS or GC frass $(40 \mu \mathrm{g} / 40 \mu \mathrm{l})$ and BAL fluid was harvested 1, 3, 6, or $18 \mathrm{~h}$ later. One hour after instillation, there was no difference in chemokine release into the BAL fluid. However, within $3 \mathrm{~h}$ there was a statistically significant increase in the level of both CCL20 (fig. 1a) and GM-CSF (fig. 1b) in the BAL fluid of GC frass-treated mice compared with PBS-treated mice. Interestingly, the levels of CCL20 continued to rise until $18 \mathrm{~h}$ after exposure, while the levels of GM-CSF were highest at $3 \mathrm{~h}$ after exposure and by $18 \mathrm{~h}$ were indistinguishable from those of PBS-treated mice. Together, these data suggest that a single exposure to GC frass is sufficient to induce an early innate immune response in mice; 


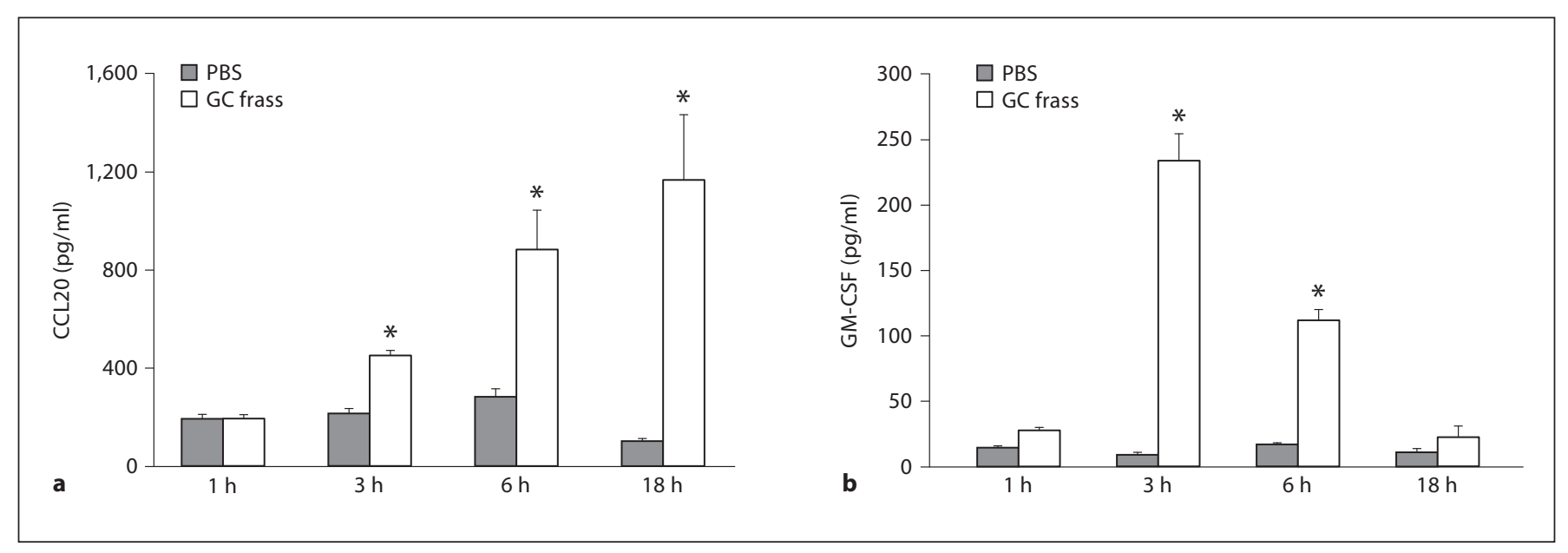

Fig. 1. A single instillation of GC frass induced CCL20 expression in the airways of mice. Balb/c mice were administered a single intratracheal instillation of PBS or GC frass $(40 \mu \mathrm{g} / 40 \mu \mathrm{l})$ 1, 3, 6, and $18 \mathrm{~h}$ later. BAL fluid was harvested, clarified, and production of CCL20 (a) and GM-CSF (b) was analyzed by ELISA. Means \pm SEM ( $\mathrm{n}=4-9$ mice per group) are reported $\left({ }^{*} \mathrm{p}<0.001\right.$ compared to PBS control) from 3 separate experiments.

however, the kinetics of CCL20 and GM-CSF release were significantly different following GC frass exposure.

\section{GC Frass Proteases Regulate the Release of CCL20 and GM-CSF into the BAL Fluid}

We have previously shown that GC frass contains active serine proteases which can regulate allergic airway inflammation [9]. To test the role of the proteases and PAR-2 activation on CCL20 release into the airways, we compared BAL levels of CCL20 $18 \mathrm{~h}$ after a single exposure to GC frass or protease-depleted GC frass. We have previously reported that aprotinin treatment inhibits $85 \%$ of the protease activity in GC frass [21]. Exposure to GC frass induced a significant increase in airway CCL20 levels, an effect that was significantly reduced when exposure to protease-depleted GC frass occurred (fig. 2a). We then asked whether functional PAR-2 was important in the GC frass-protease mediated CCL20 release. To do this, we compared CCL20 release in wild-type and PAR2-deficient mice following a single exposure to GC frass. Our data confirmed that a functional PAR-2 was important for optimal CCL20 production (fig. 2b). We also measured CCL20 production $3 \mathrm{~h}$ after instillation. At this time point, GC frass induced about a 2 -fold increase in CCL20 production, and this production was also partially dependent on the active protease and PAR-2 (data not shown).

We next asked whether the early release of GM-CSF was dependent on PAR-2 activation. Since the kinetics of
GM-CSF are different from those of CCL20, we exposed wild-type and PAR-2-deficient mice to GC frass and isolated the BAL fluid $3 \mathrm{~h}$ later. Exposure to protease-depleted GC frass resulted in significantly decreased release of GM-CSF compared to GC frass containing active proteases (fig. 3a). Using PAR-2-deficient mice, we confirmed that GM-CSF release into the airways was partially dependent on PAR-2 (fig. 3b). Analysis of GM-CSF levels in the BAL fluid of mice $18 \mathrm{~h}$ after instillation showed insignificant amounts of GM-CSF in the airways at this time point in both PBS- and GC frass-exposed mice (data not shown). Together these data suggest a role for active proteases and PAR-2 in modulating early cytokine production in mice.

\section{GC Frass Protease Is Sufficient to Induce CCL20 Production}

To further study the role of proteases in CCL20 production, we enriched the protease activity of GC frass using gel filtration. It is interesting to note that while we significantly increased the amount of protease in our preparation, we almost completely removed endotoxin from the GC frass (table 1). We asked whether the enriched protease in GC frass was sufficient to induce the innate immune response as determined by CCL20 production. The protease was administered at a dose comparable to the protease concentration found in GC frass. Our $40-\mu \mathrm{g}$ dose for instillation contains approximately 0.5 activity units; therefore, we administered 0.5 units of 


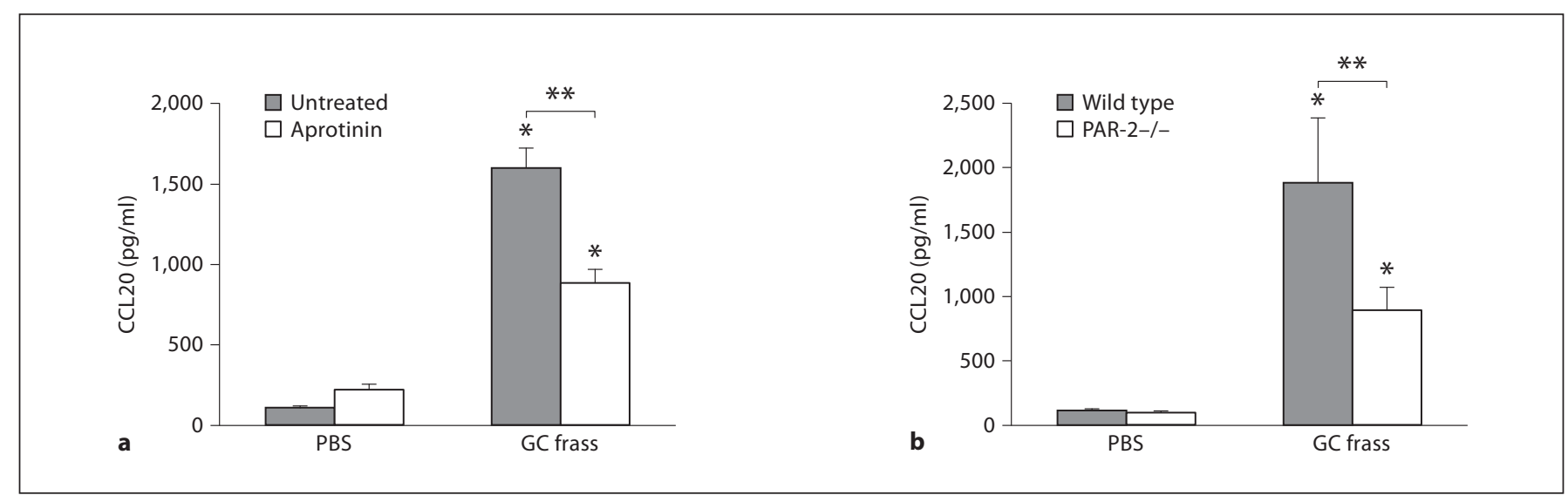

Fig. 2. GC frass proteases and PAR-2 regulate CCL20 expression in mice. a Balb/c mice were administered a single intratracheal instillation of PBS, aprotinin-treated PBS, GC frass $(40 \mu \mathrm{g} / 40 \mu \mathrm{l})$ or protease-depleted frass. BAL fluid was harvested $18 \mathrm{~h}$ later and clarified, and CCL20 was analyzed by ELISA. Means \pm SEM $\left(\mathrm{n}=6\right.$ mice per group) are reported $\left({ }^{*} \mathrm{p}=0.001 ;{ }^{* *} \mathrm{p}=0.01\right)$ from a single experiment. b Wild-type or PAR-2-deficient mice were given a single intratracheal instillation of PBS or GC frass and CCL20 levels in BAL fluid were analyzed $18 \mathrm{~h}$ later. Means \pm SEM $\left(\mathrm{n}=8\right.$ mice per group) are reported $\left({ }^{*} \mathrm{p}=0.001 ;{ }^{* *} \mathrm{p}=0.021\right)$ from 2 separate experiments.

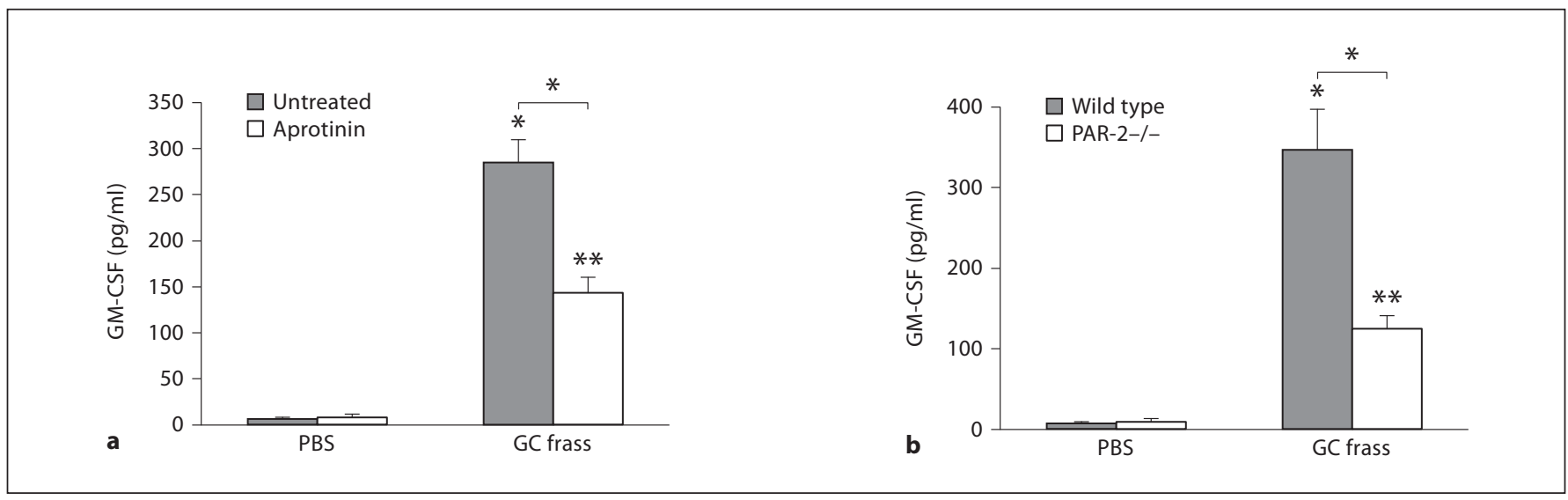

Fig. 3. GC frass proteases and PAR-2 regulate GM-CSF expression in mice. a Balb/c mice were administered a single intratracheal instillation of PBS, aprotinin-treated PBS, GC frass $(40 \mu \mathrm{g} / 40 \mu \mathrm{l})$ or protease-depleted frass and harvested $3 \mathrm{~h}$ later. BAL fluid was harvested, clarified, and GM-CSF was analyzed by ELISA. Means $\pm \operatorname{SEM}\left(\mathrm{n}=6\right.$ mice per group) are reported $\left({ }^{*} \mathrm{p}<0.001 ;{ }^{*} \mathrm{p}=\right.$

enriched protease per mouse and harvested the BAL fluid 3 and $18 \mathrm{~h}$ later. We found that the GC frass protease alone was sufficient to induce early GM-CSF (fig. 4a) and CCL20 (fig. 4b) production which was fairly comparable to the levels induced by GC frass. At the 18 -hour time point, CCL20 production was also increased compared to PBS-treated mice, but was lower than GC frass (fig. 4c). To determine if selective activation of PAR-2 was also suf-
0.01) from 2 separate experiments. b Wild-type or PAR-2-deficient mice were given a single intratracheal instillation of PBS or GC frass and GM-CSF levels in BAL fluid were analyzed $18 \mathrm{~h}$ later. Means $\pm \operatorname{SEM}\left(\mathrm{n}=8\right.$ mice per group) are reported $\left({ }^{*} \mathrm{p}<\right.$ $0.001 ;{ }^{* *} \mathrm{p}=0.021$ ) from 2 separate experiments.

ficient to mediate CCL20 production in vivo, we performed a single intratracheal instillation of a PAR-2-activating peptide (PAR-2-AP) or a scrambled control peptide (PAR-2-CP). PAR-2-AP activates PAR- 2 by bypassing the requirement for proteolytic cleavage. We confirmed that selective activation of PAR-2 was also sufficient to induce CCL20 production, while PAR-2-CP had no effect (fig. 4d). Interestingly, the levels of CCL20 production by 


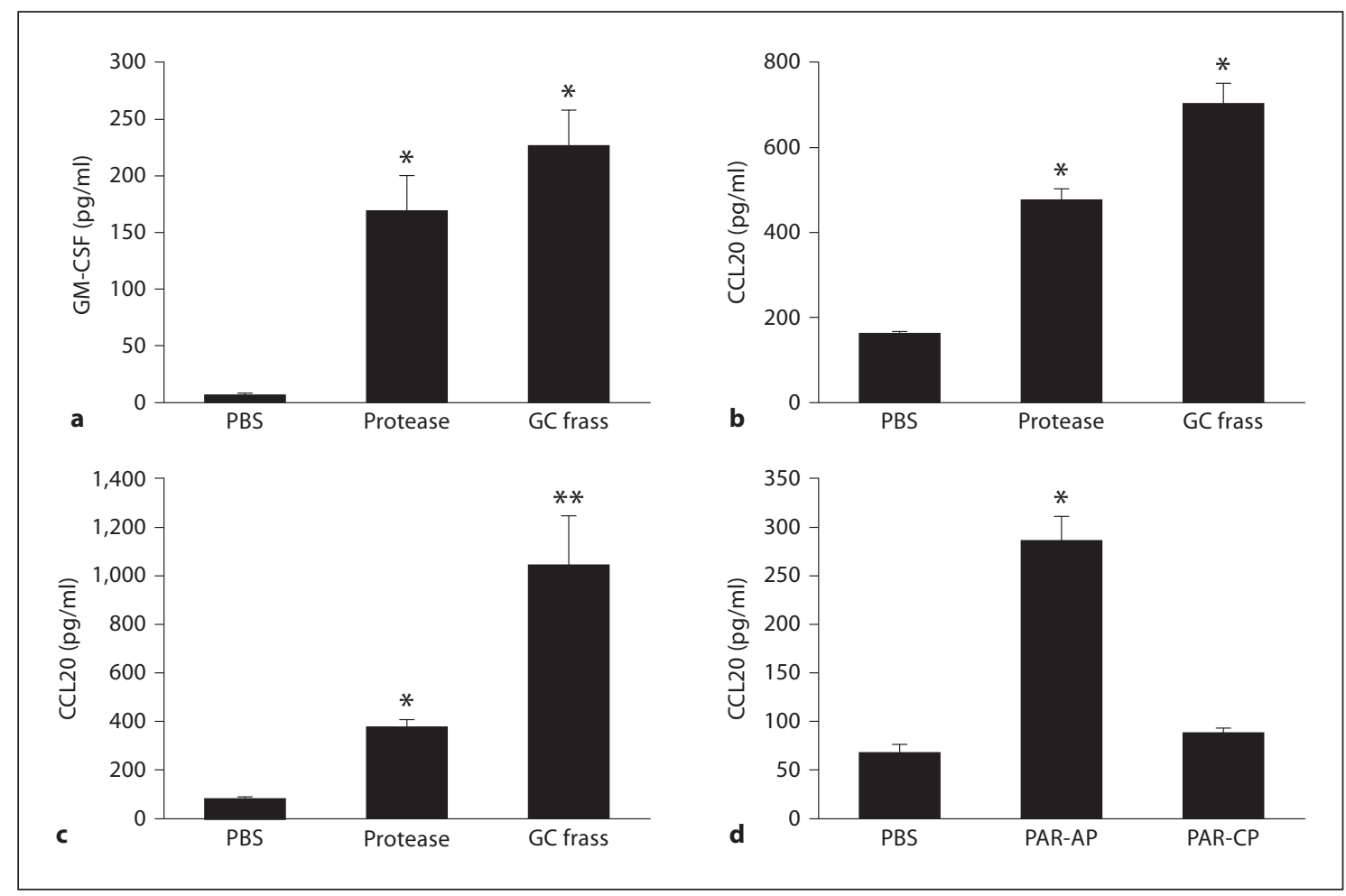

Fig. 4. Direct activation of PAR-2 with protease or PAR-2 agonist increased chemokine production. Naïve mice were administered a single instillation of protease-enriched GC frass (0.5 U) or GC frass $(40 \mu \mathrm{g})$ and BAL fluid was harvested 3 or $18 \mathrm{~h}$ later. a GMCSF levels at $3 \mathrm{~h}$ after instillation $\left({ }^{*} \mathrm{p}<0.05\right)$. $\mathbf{b}$ CCL20 levels at $3 \mathrm{~h}$ after instillation $\left({ }^{*} \mathrm{p}<0.05\right)$. c CCL20 levels at $18 \mathrm{~h}$ after in- stillation $\left({ }^{*} \mathrm{p}<0.05\right)$. d Naïve mice were administered a single instillation of PBS, PAR-2-activating peptide (PAR-2-AP), or PAR-2 control peptide (PAR-2-CP) and analyzed $18 \mathrm{~h}$ after instillation $\left({ }^{*} \mathrm{p}<0.05\right)$. In all cases, means \pm SEM $(n=4-8$ mice per group) are reported from 1 or 2 separate experiments. the active protease and the PAR-2 agonist were lower than CCL20 production by GC frass at the 18-hour time point. These data suggest an increase in the rate of cleavage or instability of the enriched protease compared to GC frass, or suggests the possibility that other activators may also be required for maximal CCL20 release. GM-CSF levels are below the level of detection by $18 \mathrm{~h}$ after instillation.

\section{GC Frass Proteases and PAR-2 Regulate CCL20 and} GM-CSF Production from Airway Epithelial Cells

To determine if exposure to GC frass altered airway epithelial cell production of CCL20 and GM-CSF, we cultured primary MTECs from wild-type mice with PBS, aprotinin-treated PBS, GC frass or aprotinin-treated GC frass. Ex vivo treatment of MTECs with protease-depleted GC frass resulted in decreased CCL20 and GM-CSF production when compared to treatment with proteasecontaining GC frass (fig. 5a, b). To determine if a functional PAR-2 was required for the production of these chemokines, we cultured primary MTECs from wildtype and PAR-2-deficient mice and treated them with GC frass. We found that PAR-2-deficient MTECs produced less CCL20 and GM-CSF than the MTECs from wildtype mice (fig. $5 \mathrm{c}, \mathrm{d}$ ). These data suggest that the active proteases in GC frass and PAR-2 regulate CCL20 and GM-CSF production from airway epithelial cells.

\section{GC Frass Proteases and PAR-2 Are Sufficient for Increased $m D C$ s in the Lung}

Since GC frass proteases and PAR-2 were sufficient to regulate GM-CSF and CCL20 production, we tested whether protease-PAR-2 activation could alter the recruitment of DCs into the lung. To do this, we performed a single intratracheal instillation of PBS or AF405-GC frass into wild-type or PAR-2-deficient mice. Twenty hours later, lungs were removed, cells isolated and stained for flow cytometry. We classified the mDCs as CD11c+, CD11b+, Gr1- CD317- (data not shown). Exposure to GC 


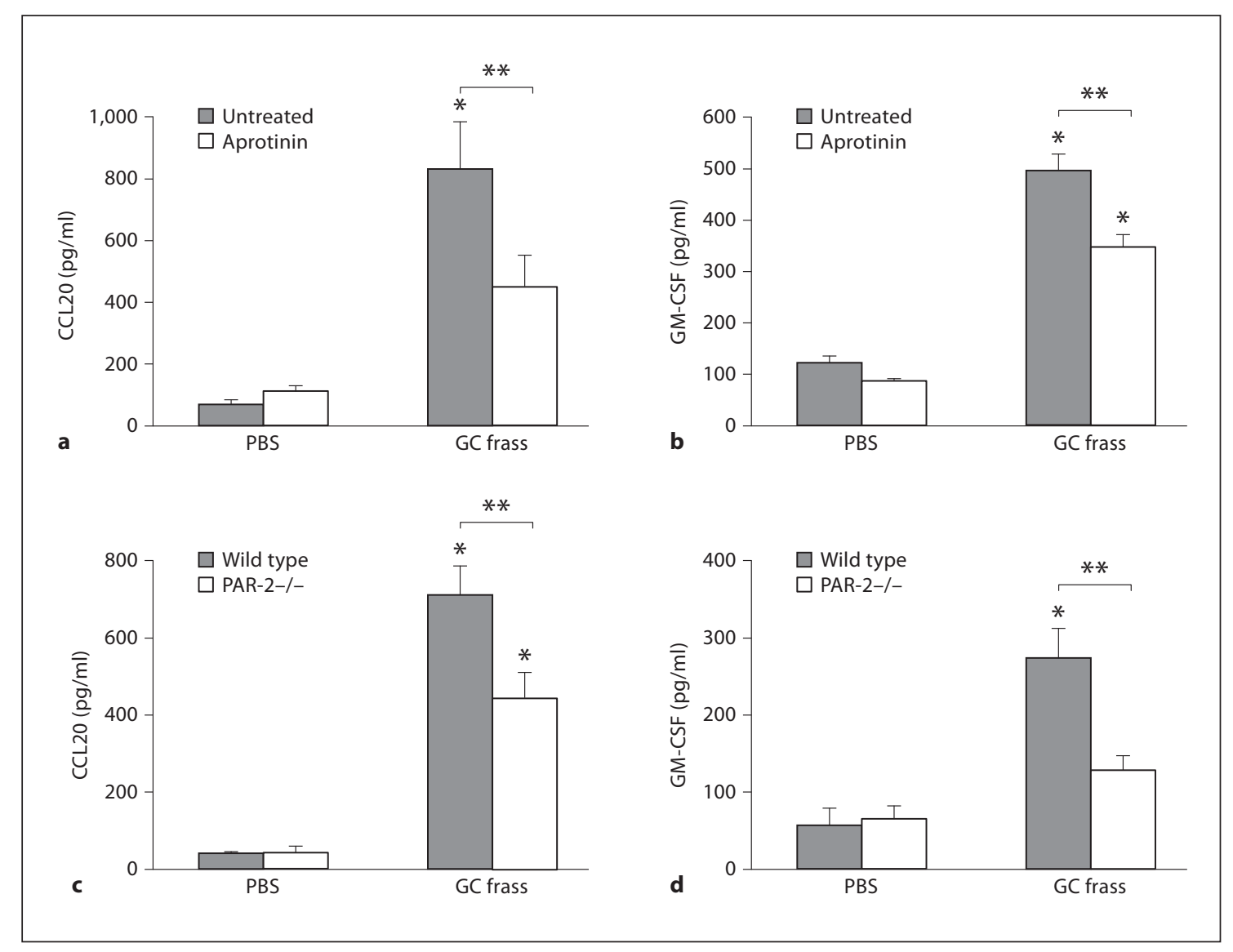

Fig. 5. CCL20 and GM-CSF expression from MTECs. Tracheas from mice were isolated and MTECs were cultured in transwell plates until confluent. MTECs were treated with PBS, aprotinintreated PBS, GC frass (300 ng/ml), or protease-depleted frass GC frass $(300 \mathrm{ng} / \mathrm{ml})$ for $18 \mathrm{~h}$. Cell supernatants were harvested, clarified and analyzed for CCL20 (a; $\left.{ }^{*} \mathrm{p}<0.001,{ }^{* *} \mathrm{p}=0.017\right)$ or GM-

frass led to an increased percentage of pulmonary mDCs in wild-type mice (fig. 6a). The percentage of mDCs in the airways following GC frass instillation in PAR-2-deficient mice was significantly less than in the wild-type mice. We next asked whether differential uptake of GC frass occurred in PAR-2-deficient mice. We measured the amount of AF405-labeled GC frass in the mDC population in the lung. We found that there was no significant difference in the percentage of mDCs that had taken up AF405-GC frass between the wild-type and PAR-2-deficient mice (fig. 6b). Together, these data suggest that the lower levels of mDCs, but not differential uptake of allergen, may be responsible for the decreased allergic airway inflammation we have previously shown in these mice [9].
$\operatorname{CSF}\left(\mathbf{b} ;{ }^{*} \mathrm{p}=0.001,{ }^{* *} \mathrm{p}=0.005\right)$ by ELISA. Mean \pm SEM are reported from 5 separate experiments. MTECs were cultured from wild-type or PAR-2-deficient mice. Cell supernatants were harvested, clarified and analyzed for CCL20 (c; ${ }^{*} \mathrm{p}<0.001$, $\left.{ }^{* *} \mathrm{p}=0.019\right)$ or GM-CSF $\left(\mathbf{d} ;{ }^{*} \mathrm{p}=0.002,{ }^{* *} \mathrm{p}=0.004\right)$ by ELISA. Mean \pm SEM are reported from 3 or 4 separate experiments.

\section{Discussion}

Herein we describe a role for allergen-derived proteases and PAR-2 in the release of CCL20 and GM-CSF into the airways of mice following a single exposure to GC frass. GC frass is complex and contains a number of components including active serine proteases [23], endotoxin [23], a TLR2 agonist [24], and a number of unknown components. In this report, our goal was to assess the effect of the protease component(s) in GC frass on their ability to induce chemokine production in vivo. To do this, we used a variety of reagents, including proteasedepleted GC frass, protease-enriched GC frass and PAR2 -deficient mice. We found that the kinetics of GM-CSF and CCL20 release are different following in vivo expo- 

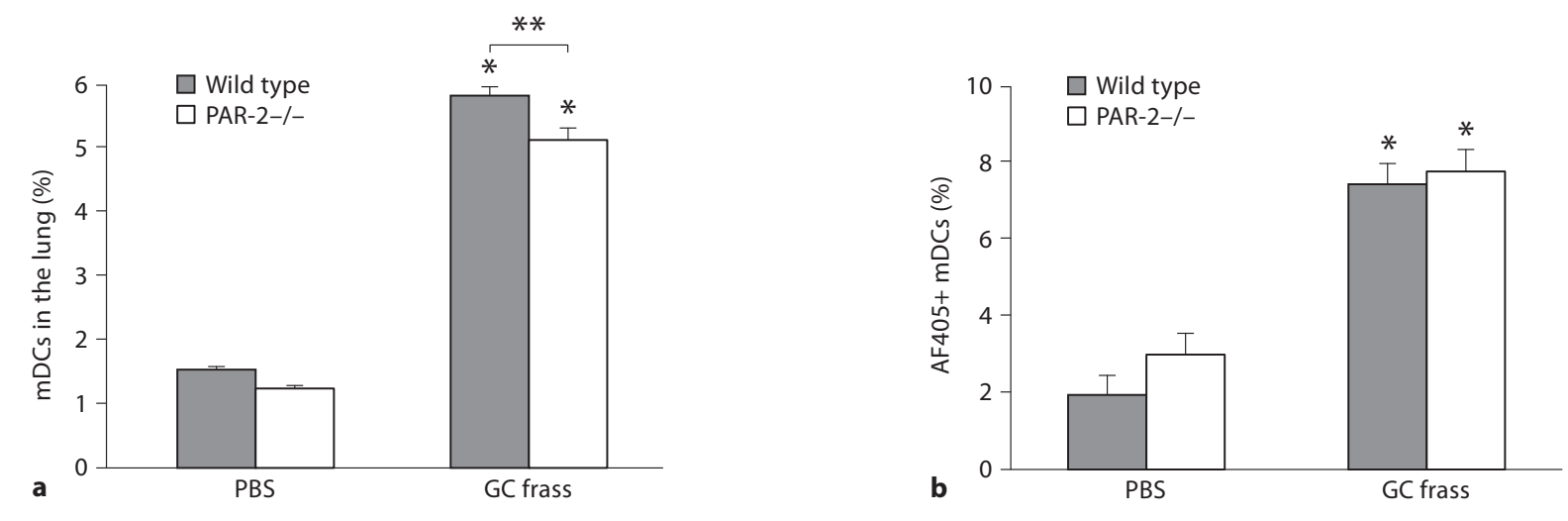

Fig. 6. Percentage of $\mathrm{mDC}$ and allergen uptake in $\mathrm{mDC}$ following AF405-GC frass exposure. Wild-type and PAR-2-deficient mice were exposed to a single intratracheal instillation of PBS or Alexa-Fluor (AF) 405-labeled GC frass (40 $\mu \mathrm{g} / 40 \mu \mathrm{l})$. Whole lungs were isolated $20 \mathrm{~h}$ later and cells were dissociated and stained for flow cytometric analysis. Cells were gated only on
mDCs (CD11c+, CD11b+, Gr1-, CD317-). a Percentage of mDCs in the lung $\left({ }^{*} \mathrm{p}<0.001,{ }^{* *} \mathrm{p}=0.007\right)$. b Percentage of AF405positive $\mathrm{mDC}$ in the lung $\left({ }^{*} \mathrm{p}<0.001\right)$. Mean $\pm \mathrm{SEM}$ are reported from 6 mice per group with the samples being run in quintuplicate in a single experiment. sure to GC frass, in that GM-CSF peaks early while CCL20 has more of a delayed release. While the mechanism responsible for differences in the kinetics of GMCSF and CCL20 release are unclear, we speculate that the early burst of GM-CSF may be to facilitate DC activation/ maturation. As mature DCs will then migrate from the lung to the lung-draining lymph nodes, the subsequent burst of CCL20 release may be responsible for replacing the mature DCs with immature DCs recruited directly from the circulation. In support of this, it has been demonstrated that allergen-bearing, activated DCs can be observed in the lung-draining lymph nodes as rapidly as $6 \mathrm{~h}$ after allergen exposure [25].

We confirmed that these chemokines are being synthesized by the airway epithelium, and are likely first responders to allergen exposure. It is not surprising that allergen-derived proteases can act directly on airway epithelium as we have previously shown the role of proteases in regulating signaling pathways following PAR-2 activation [23, 26, 27]. Other reports have also investigated the importance of the allergen-associated protease in regulating CCL20 production in vitro. Pichavant et al. [28] showed that the proteolytically active Der p1 induced CCL20 while the inactive form, pro-Der p1, failed to regulate CCL20 production in BEAS- $2 \mathrm{~B}$ cells. In addition, they showed that chemical inhibition of Der pl protease activity also inhibited CCL20 production, suggest- ing that its action is linked to its protease activity. Trypsin has been shown to induce PAR-2-mediated CCL20 production in human gingival epithelial cells [29]. However, Nathan et al. [14] recently showed that HDM-induced CCL20 production in the human airway epithelial cell line 16HBE14o- cells was independent of protease activity. The protease activity in the HDM preparation was not discussed in that study, so it is unclear how much protease activity was initially in the HDM preparation. In the current study, we enriched the protease in GC frass using column chromatography methods. Our data indicate that the enriched protease can induce GM-CSF and CCL20 production at a level similar to that of GC frass at $3 \mathrm{~h}$ after instillation. Interestingly though, at $18 \mathrm{~h}$ after instillation, the levels of CCL20 production from the enriched protease were substantially lower than those from GC frass. One interpretation of these data is that enrichment of the protease may remove a component in GC frass that aids in the stabilization of the protease or in protection from degradation. It is likely that endogenous pulmonary antiproteases (i.e. serine leukocyte protease inhibitor or $\alpha_{1}$ antitrypsin) could inactivate the enriched protease at an increased rate, or with increased potency.

Interestingly, a consequence of the enrichment of the protease was the removal of endotoxin. We have previously attempted to remove the endotoxin using a com- 
mercially available endotoxin-removal column; however, we were unsuccessful in removing more than $50 \%$ of the endotoxin [K. Page, unpublished observation]. It is important to note that endotoxin was not the only component removed from GC frass during the enrichment procedure and at this point it is unclear what role these unknown components have on chemokine production. Complete removal of endotoxin often includes very harsh conditions (i.e. exposure to acids or alkalis at concentrations equal to or higher than $0.1 \mathrm{M}$ or temperatures of $250^{\circ} \mathrm{C}$ for $30 \mathrm{~min}$ ) which would also alter the activity of a serine protease. Since we were unable to selectively remove endotoxin from GC frass while retaining the presence of proteases and other proteins, we cannot conclude in the present study that endotoxin plays a major role in regulating CCL20 and GM-CSF production. In addition, treatment with commercially available 'purified' endotoxin may not be similar to the endotoxin found in GC frass. Thus, while it is possible that endotoxin plays a role in mediating these effects, the overall goal of this study was to examine the ability of the active serine protease in GC frass to regulate chemokine expression in vivo.

At this point, we have no evidence to suggest that PAR-2-deficient mice are unable to mount a normal immune response because of an abnormality in the DC population. While Fields et al. [30] showed that DCs do not spontaneously develop from the bone marrow of PAR-2-deficient mice, a subsequent study failed to find a direct role for PAR-2 in the differentiation of bone marrow from wild-type and PAR-2-deficient mice into bone marrow DCs when cultured in the presence of GM-CSF [31]. In addition, there was no difference between DC subset frequencies in the lymph nodes of PAR-2-deficient mice compared to wild-type mice [31]. In our study, there was no difference in the numbers of $\mathrm{mDCs}$ in the PBS-stimulated PAR-2-deficient mice compared to wildtype mice. If PAR-2 deficiency was responsible for the development of DCs, we would expect a lack of DCs in the lung even in the unchallenged state. One difference between our work and that of Ramelli et al. is that they found that selective PAR-2 activation increased maturation of bone marrow DCs as evidenced by increased MHC class II and CD86 expression on DCs and that PAR-2-deficient mice demonstrated a reduced frequency of FITC+ DCs following FITC painting [31]. While we did not study the maturation of bone marrow DCs in the presence of GC frass proteases in this study, our results did not show any differences in the uptake of Alexa-Fluor 405-labeled GCs by pulmonary DCs between wildtype and PAR-2-deficient mice. The reasons for this are unclear, but may reflect differences in mechanisms of allergen uptake between small molecules (FITC) and complex antigens (GC frass) or differences in PAR-2 biology between DCs at epidermal versus mucosal sites. Further study is needed to determine the root cause of these differences.

GM-CSF is clearly a proallergic signal, as overexpression of GM-CSF was shown to induce allergic airway inflammation to ovalbumin exposure compared to ovalbumin exposure alone [18]. Our data demonstrate that the complex allergen GC frass can directly induce GMCSF expression from epithelial cells in a mechanism at least partially dependent on PAR-2 activation. In support of this, BEAS-2B cells treated with Der p1 or Der p9 were shown to produce GM-CSF [32], and Der p3 and Der $\mathrm{p} 9$ were shown to activate PAR-2 and induce the release of GM-CSF [33]. Another study confirmed that recombinant allergens Der $\mathrm{f} 1$ and Der $\mathrm{p} 1$ stimulated the production of GM-CSF in normal human keratinocytes and this could be inhibited by the addition of cystatin A (a cysteine proteinase inhibitor) [34]. Normal and asthmatic bronchial epithelial cells have been shown to release GM-CSF following Der p exposure [35] and, recently, nasal biopsies from patients with chronic rhinosinusitis without nasal polyps had increased PAR-2 expression [36]. Collectively, these studies suggest that PAR-2 activation by protein allergens can induce GMCSF production by epithelial cells, suggesting a possible mechanism by which allergen exposure could initiate allergic responses.

Overall, the findings in this study show that the protease-PAR-2 plays a role in GM-CSF and CCL20 production in the airways of mice. The subsequent infiltration and/or differentiation of mDCs could be sufficient to initiate allergic airways in the presence of allergen. It is important to consider that the relatively small, but statistically significant change in the percentage of mDCs in the airways of wild-type and PAR-2-deficient mice following GC frass exposure was performed on whole lung. It is possible that if we looked directly at the actual differences in $\mathrm{mDC}$ populations in a local microenvironment, these changes might be greater. We anticipate that in the upper airways where the instillation of GC frass is likely to be the most concentrated, there may be even higher levels of mDC recruitment. In our study, it does not appear that PAR-2 plays a role in antigen uptake, but it is possible that an additional role for PAR-2 could be in the regulation of the overall maturation state of the DCs, the ability of DCs to process and present antigen, or in the migration of activated DCs to the draining lymph nodes, 
where $\mathrm{T}$ cell activation can occur. Elucidation of the mechanism by which proteases associated with allergens can initiate and/or augment the early innate immune response may ultimately lead to a better understanding of how an allergen is able to elicit a shift from tolerance to disease.

\section{Acknowledgements}

We thank Dr. Gary Bennett for providing the GC frass. This work was supported by the National Institutes of Health Grant HL075568 (KP), American Medical Association Seed Research Grant (SD), and partially supported by NIH grant AR47363 for the flow cytometry core at CCHMC.

\section{References}

1 Asokananthan N, Graham PT, Stewart DJ, Bakker AJ, Eidne KA, Thompson PJ, Stewart GA: House dust mite allergens induce proinflammatory cytokines from respiratory epithelial cells: the cysteine protease allergen, Der $\mathrm{p}$ 1, activates protease-activated receptor (PAR)-2 and inactivates PAR-1. J Immunol 2002;169:4572-4578.

$\checkmark 2$ Chiu LL, Perng DW, Yu CH, Su SN, Chow LP: Mold allergen, Pen c 13, induced IL-8 expression in human airway epithelial cells by activated protease-activated receptor 1 and 2 . J Immunol 2007; 178:5237-5244.

- 3 Hong JH, Lee SI, Kim KE, Yong TS, Seo JT, Sohn MH, Shin DM: German cockroach extract activates protease-activated receptor 2 in human airway epithelial cells. J Allergy Clin Immunol 2004;113:315-319.

-4 Scarborough RM, Naughton MA, Teng W, Hung DT, Rose J, Vu TK, Wheaton VI, Turck CW, Coughlin SR: Tethered ligand agonist peptides. Structural requirements for thrombin receptor activation reveal mechanism of proteolytic unmasking of agonist function. J Biol Chem 1992;267:1314613149.

5 Colognato R, Slupsky JR, Jendrach M, Burysek L, Syrovets T, Simmet T: Differential expression and regulation of protease-activated receptors in human peripheral monocytes and monocyte-derived antigen-presenting cells. Blood 2003;102:2645-2652.

-6 Howells GL, Macey MG, Chinni C, Hou L, Fox MT, Harriott P, Stone SR: Proteinaseactivated receptor-2: expression by human neutrophils. J Cell Sci 1997;110:881-887.

-7 D'Andrea MR, Rogahn CJ, Andrade-Gordon P: Localization of protease-activated receptors- 1 and -2 in human mast cells: indications for an amplified mast cell degranuation cascade. Biotech Histochem 2000;75: 85-90.

8 Page K, Lierl K, Herman N, Wills-Karp M: Differences in susceptibility to German cockroach frass and its associated proteases in induced allergic inflammation in mice. Respir Res 2007;8:91.

9 Page K, Ledford JR, Zhou P, Wills-Karp M: Mucosal sensitization to German cockroach involves protease-activated receptor- 2 . Respir Res 2010;11:62.
10 Jahnsen FL, Strickland DH, Thomas JA, Tobagus IT, Napoli S, Zosky GR, Turner DJ, Sly PD, Stumbles PA, Holt PG: Accelerated antigen sampling and transport by airway mucosal dendritic cells following inhalation of a bacterial stimulus. J Immunol 2006;177: 5861-5867.

11 Jahnsen FL, Moloney ED, Hogan T, Upham JW, Burke CM, Holt PG: Rapid dendritic cell recruitment to the bronchial mucosa of patients with atopic asthma in response to local allergen challenge. Thorax 2001;56:823-826.

-12 Weckmann M, Collison A, Simpson JL, Kopp MV, Wark PA, Smyth MJ, Yagita H, Matthaei KI, Hansbro N, Whitehead B, Gibson PG, Foster PS, Mattes J: Critical link between TRAIL and CCL20 for the activation of Th2 cells and the expression of allergic airway disease. Nature Med 2007;13:13081315.

13 Dieu MC, Vanbervliet B, Vicari A, Bridon JM, Oldham E, Aït-Yahia S, Brière F, Zlotnik A, Lebecque S, Caux C: Selective recruitment of immature and mature dendritic cells by distinct chemokines expressed in different anatomic sites. J Exp Med 1998;188:373-386.

14 Nathan AT, Peterson EA, Chakir J, WillsKarp M: Innate immune responses of airway epithelium to house dust mite are mediated through $\beta$-glucan-dependent pathways. J Allergy Clin Immunol 2009;123:612-618.

15 Esashi E, Wang YH, Perng O, Qin XF, Liu YJ, Watowich SS: The signal transducer STAT5 inhibits plasmacytoid dendritic cell development by suppressing transcription factor IRF8. Immunity 2008;28:509-520.

16 de Heer HJ, Hammad H, Soullié T, Hijdra D, Vos N, Willart MA, Hoogsteden HC, Lambrecht BN: Essential role of lung plasmacytoid dendritic cells in preventing asthmatic reactions to harmless inhaled antigen. J Exp Med 2004;200:89-98.

17 Cates EC, Fattouh R, Wattie J, Inman MD, Goncharova S, Coyle AJ, Gutierrez-Ramos JC, Jordana M: Intranasal exposure of mice to house dust mite elicits allergic airway inflammation via a GM-CSF-mediated mechanism. J Immunol 2004;173:6384-6392.
18 Stämpfli MR, Wiley RE, Neigh GS, Gajewska BU, Lei XF, Snider DP, Xing Z, Jordana M: $\mathrm{Gm}$-Csf transgene expression in the airway allows aerosolized ovalbumin to induce allergic sensitization in mice. J Clin Invest 1998;102:1704-1714.

19 Chavira RCJ, Burnett TJ, Hageman JH: Assaying proteinases with azocoll. Anal Biochem 1984;136:446-450.

20 Bhat RK, Page K, Tan A, Hershenson MB: German cockroach extract increases bronchial epithelial cell interleukin-8 expression. Clin Exp Allergy 2003;33:35-42.

21 Hughes VS, Page K: German cockroach frass proteases cleave pro-matrix metalloproteinase-9. Exp Lung Res 2007;33:135-150.

22 Walters DM, Breysse PN, Wills-Karp M: Ambient urban Baltimore particulate-induced airway hyperresponsiveness and inflammation in mice. Am J Respir Crit Care Med 2001;164:1438-1443.

23 Page K, Hughes VS, Bennett GW, Wong HR: German cockroach proteases regulate matrix metalloproteinase-9 in human bronchial epithelial cells. Allergy 2006;61:988-995.

24 Page K, Lierl KM, Hughes VS, Zhou P, Ledford JR, Wills-Karp M: TLR2-mediated activation of neutrophils in response to German cockroach frass. J Immunol 2008; 180:63176324.

25 Vermaelen KY, Carro-Muino I, Lambrecht BN, Pauwels RA: Specific migratory dendritic cells rapidly transport antigen from the airways to the thoracic lymph nodes. J Exp Med 2001;193:51-60.

26 Page K, Hughes VS, Odoms KK, Dunsmore KE, Hershenson MB: German cockroach proteases regulate IL-8 expression via NFIL6 in human bronchial epithelial cells. Am J Respir Cell Mol Biol 2005;32:225-231.

27 Page K, Strunk VS, Hershenson MB: Cockroach proteases increase IL-8 expression in human bronchial epithelial cells via activation of protease-activated receptor (PAR)-2 and ERK. J Allergy Clin Immunol 2003;112: 1112-1118.

28 Pichavant $\mathrm{M}$, Charbonnier AS, Taront $\mathrm{S}$, Brichet A, Wallaert B, Pestel J, Tonnel AB, Gosset P: Asthmatic bronchial epithelium activated by the proteolytic allergen Der $\mathrm{p} 1$ increases selective dendritic cell recruitment. J Allergy Clin Immunol 2005; 115:771778. 
29 Rohani MG, Beyer RP, Hacker BM, Dommisch H, Dale BA, Chung WO: Modulation of expression of innate immunity markers CXCL5/ENA-78 and CCL20/MIP3 $\alpha$ by protease-activated receptors (PARs) in human gingival epithelial cells. Innate Immun 2010; 16:104-114.

30 Fields RC, Schoenecker JG, Hart JP, Hoffman MR, Pizzo SV, Lawson JH: Protease-activated receptor-2 signaling triggers dendritic cell development. Am J Path 2003;162: 1817-1822.

- 31 Ramelli G, Fuertes S, Busso N, Acha-Orbea $\mathrm{H}$, So A: Protease-activated receptor 2 signalling promotes dendritic cell antigen transport and T-cell activation in vivo. Immunol 2010;129:20-27.
2 King C, Brennan S, Thompson PJ, Stewart GA: Dust mite proteolytic allergens induce cytokine release from cultured airway epithelium. J Immunol 1998;161:3645-3651.

33 Sun G, Stacey MA, Schmidt M, Mori L, Mattoli S: Interaction of mite allergens Der $\mathrm{p} 3$ and Der p 9 with protease-activated receptor-2 expressed by lung epithelial cells. J Immunol 2001;167:1014-1021.

34 Ogawa T, Takai T, Kato T, Kikuchi Y, Niyonsaba F, Ikeda S, Okumura K, Ogawa H: Upregulation of the release of granulocytemacrophage colony-stimulating factor from keratinocytes stimulated with cysteine protease activity of recombinant major mite allergens, Der f 1 and Der $\mathrm{p} 1$. Int Arch Allergy Immunol 2008;146:27-35.
35 Lordan JL, Bucchieri F, Richter A, Konstantinidis A, J.W. H, Thornber M, Puddicombe SM, Buchanan D, Wilson SJ, Djukanovic R, Holgate ST, Davies DE: Cooperative effects of Th 2 cytokines and allergen on normal and asthmatic bronchial epithelial cells. J Immunol 2002;169:407-414.

36 Rudack C, Steinhoff M, Mooren F, Becker K, von Eiff C, Sachse F: PAR-2 activation regulastes IL- 8 and GRO- $\alpha$ synthesis by NF- $\kappa$ B, but not RANTES, IL-6, eotaxin, or TARC expression in nasal epithelium. Clin Exp Allergy 2007;37:1009-1022. 